University of Nebraska - Lincoln

DigitalCommons@University of Nebraska - Lincoln

Faculty Publications from the Harold W. Manter Laboratory of Parasitology

1955

Reproduction in the Wolverine, Gulo gulo

\author{
Philip L. Wright \\ Montana State University \\ Robert L. Rausch \\ Arctic Health Research Center, rausch@u.washington.edu
}

Follow this and additional works at: https://digitalcommons.unl.edu/parasitologyfacpubs

Part of the Parasitology Commons

Wright, Philip L. and Rausch, Robert L., "Reproduction in the Wolverine, Gulo gulo" (1955). Faculty Publications from the Harold W. Manter Laboratory of Parasitology. 526.

https://digitalcommons.unl.edu/parasitologyfacpubs/526

This Article is brought to you for free and open access by the Parasitology, Harold W. Manter Laboratory of at DigitalCommons@University of Nebraska - Lincoln. It has been accepted for inclusion in Faculty Publications from the Harold W. Manter Laboratory of Parasitology by an authorized administrator of DigitalCommons@University of Nebraska - Lincoln. 


\title{
REPRODUCTION IN THE WOLVERINE, GULO GULO
}

\author{
By Philip L. Wright and Robert Rausch
}

The reproductive habits of the wolverine, largest of the terrestrial mustelids, have remained largely unknown. In the American literature there are scattered statements indicating that the young are born in the spring and that the number of young at birth is from two to four (Seton, 1927). Seton also states that mating takes place in March and the young are born in June. These statements, which are only partially correct, have come largely from woodsmen who have made no detailed study of the species. Mohr $(1938,1939)$ states that breeding occurred between July 17 and 22, 1915, in a pair of captive European wolverines kept at the Copenhagen Zoo and the female gave birth to a litter on February 17, 1916. The same female produced another litter on February 24, 1917 after breeding the previous summer. She suggests that the European wolverine has a gestation period of about nine months. Recently Rausch (1953) has concluded that the American and European wolverines belong to the same species (Gulo gulo). The above evidence and the known occurrence of delayed implantation with the accompanying long periods of gestation in several mustelids suggest that this species should be more thoroughly investigated.

The collection of Alaskan mammals carried on under the direction of the junior author since January, 1949, is an important activity of the Animal-borne Disease Branch of the Arctic Health Research Center. The material thus far obtained has been utilized for studies of diseases and helminth parasites, and has provided information of interest to mammalogists. In the course of these collections Rausch obtained several wolverines in 1949 and 1950 and some female reproductive tracts were sent to Wright for study.

In species in which breeding occurs in mid-summer and the young are born the following spring, the reproductive tracts of those females destined to produce young in the spring will show no macroscopic signs of pregnancy if the animals are killed in the fall and early winter. If the ovaries and uteri are histologically sectioned, inactive corpora lutea will be found in the ovaries and unimplanted blastocysts in the uteri (Hamlett, 1935, Wright, 1942). When histological examination of one of the first tracts obtained from a female wolverine showed corpora lutea and unimplanted blastocysts, it was decided to study reproduction as fully as possible in this species.

We are indebted to Drs. H. W. Mossman and C. H. Conaway who examined the slides, read the manuscript, and made numerous helpful suggestions.

\section{MATERIALS AND METHODS}

The wolverines examined by Rausch to date, more than 50 in number, have been secured largely through the cooperation of trappers. Never an abundant animal, the wolverine is continuously persecuted, and since July 1, 1953, the Territory of Alaska has paid a bounty on this animal. The animals were examined soon after death, or were frozen until examination was possible. After recording 
TABLE 1.-Findings in female reproductive tracts of Gulo

\begin{tabular}{|c|c|c|c|c|c|}
\hline \multirow{2}{*}{ Date killed } & \multicolumn{2}{|c|}{$\begin{array}{l}\text { Weight of } \\
\text { ovaries }\end{array}$} & \multicolumn{2}{|c|}{$\begin{array}{l}\text { Distribution of } \\
\text { corpora lutea }\end{array}$} & \multirow{2}{*}{ Remarks } \\
\hline & Right & Left & Right & Left & \\
\hline Oct. $18,{ }^{\prime} 53$ & 243 & 244 & 1 & 3 & 2 blastocysts, 1 dead embryo \\
\hline Nov. 1, '51 & 143 & 152 & 2 & 2 & 4 blastocysts \\
\hline Jan. '50 & 28 & 63 & - & - & \\
\hline Jan. '50 & 158 & 180 & 2 & 2 & 4 blastocysts \\
\hline Jan. 20, '53 & 291 & 303 & 2 & 3 & $\begin{array}{l}3 \text { embryos, } 1 \text { resorbing embryo } \mathrm{R}, 3 \mathrm{~L}(22 \\
\mathrm{mm} \text {. CR) }\end{array}$ \\
\hline Jan. 25, '50 & 160 & 157 & - & - & \\
\hline Jan. 26, '53 & 107 & 110 & - & - & \\
\hline Feb. 2, '53 & 430 & 420 & 2 & 2 & 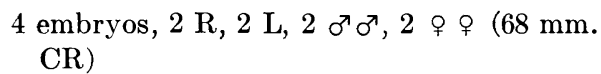 \\
\hline Mar. 21, '52 & 89 & 95 & - & - & \\
\hline Apr. 9, '53 & 202 & 199 & 4 & 0 & Lactating; placental scars-2 R, $2 \mathrm{~L}$ \\
\hline Apr. 10, '53 & 179 & 220 & 4 & 0 & Lactating; placental scars $-2 \mathrm{R}, 1 \mathrm{~L}$ \\
\hline
\end{tabular}

appropriate measurements and other data, the animals were autopsied in order to collect internal parasites and other materials. The genital organs were fixed in 10 per cent formalin or A.F.A. The skulls and bacula were cleaned by dermestid beetles and bleached in hydrogen peroxide. All the skeletal material was handled uniformly. This report summarizes data from 22 males and 11 females obtained in northern Alaska from the fall of 1950 through the fall of 1953. The fixed reproductive tracts and the cleaned skulls and bacula were sent to Wright who studied the material.

Female tracts. - The ovaries were dissected free from the surrounding bursa, weighed to the nearest milligram, dehydrated in dioxan, infiltrated and imbedded in paraffin, and serially sectioned at 10 microns (Table 1). Representative sections were stained in hematoxylin and eosin or Groat's quadruple stain, and the slides studied. If corpora lutea were found in the ovaries of animals without macroscopically visible embryos, the upper third of the corresponding uterine horn was cut off, serially sectioned, and the sections searched for blastocysts. If blastocysts corresponding in number to the corpora lutea in the ovary were located, no further sectioning of that uterine horn was done. If all the blastocysts were not located in the first piece of uterus, the middle third was handled in the same way, and even the basal third was sectioned in some cases. Measurements were made of the corpora lutea and the blastocysts with an ocular micrometer and by counting the number of sections through which the structures extended.

Male tracts. - Each testis was dissected free of the tunica vaginalis, the vas deferens cut off close to the testis, and the combined weight of the paired testes and epididymides taken. A portion of one testis and the tail of the epididymis was cut out, sectioned, and stained. The presence or absence of sperm in both the testis and epididymis was determined.

Skulls and bacula.-Many of the usual cranial measurements were taken and 
the skulls were studied for characters that might be useful in estimating age. After cleaning, the bacula were allowed to dry for several weeks and weighed to the nearest milligram.

\section{OBSERVATIONS}

Females.-The female reproductive tract is typical of the Mustelidae. The ovary is enclosed in a bursa but there is an ostium out through which a portion of the fimbria extends. The uterus is bicornuate and the common lumen of the body is quite short. The fixed uterine horns in immature animals taken during the winter are about $60 \mathrm{~mm}$. long by $3 \mathrm{~mm}$. in diameter. In adults taken in fall or early winter the horns are about $90 \mathrm{~mm}$. long and $5 \mathrm{~mm}$. in diameter. No os clitoridis could be located macroscopically in the one adult vulvar region preserved.

The ovaries of immature females taken during the fall and winter months are without corpora lutea or large follicles. The cortical and medullary regions are distinct. The outer cortex shows many primary follicles and some medium sized follicles. The remainder of the cortex which comprises the largest portion of the ovary consists of large masses of interstitial gland cells, many of which develop from the theca of atretic follicles forming corpora atretica. Other cords of interstitial gland cells extend from the stroma of the tunica albuginea to the medullary stroma and these cells are probably derived from the stroma. The medulla is fibrous with numerous blood vessels and scattered clumps of small interstitial gland cells.

The ovaries of adult females taken during the fall and early winter tend to be somewhat larger than those of the immatures and they show inactive corpora lutea (Pl. I). There are one to three corpora per ovary and they are from $1.65 \mathrm{~mm}$ to $2.00 \mathrm{~mm}$ in diameter on the stained slides. The corpora do not bulge from the surface of the ovary and they are not distinctly visible externally, but they could be seen easily macroscopically if the ovary were sectioned with a razor blade or sharp knife. The cells of these corpora are small, and in the November and January specimens are vacuolated like those seen in the corpora of winter killed marten (Wright, 1942). The cortical interstitial tissue is well developed in all three of the animals in inactive pregnancy and comprises the largest portion of the ovary. The medullary interstitial cells are especially well developed in the October specimen. They occur as scattered cords of large glandular cells. The October specimen shows some small follicles with antra and many corpora atretica, but the November and January specimens are without follicles with antra, and atretic follicles still showing degenerating eggs are extremely rare.

The ovaries of the two animals in active pregnancy are the largest (Pl. I). Their corpora range from $3.38 \mathrm{~mm}$. to $3.60 \mathrm{~mm}$. and they are nearly seven times the volume of the inactive corpora of specimens taken earlier in the season before implantation. These corpora are very conspicuous externally in the intact ovary and some even appear to be attached to it by short pedicles only. The corpora are highly vascularized and show very large secretory cells without vacuoles. 

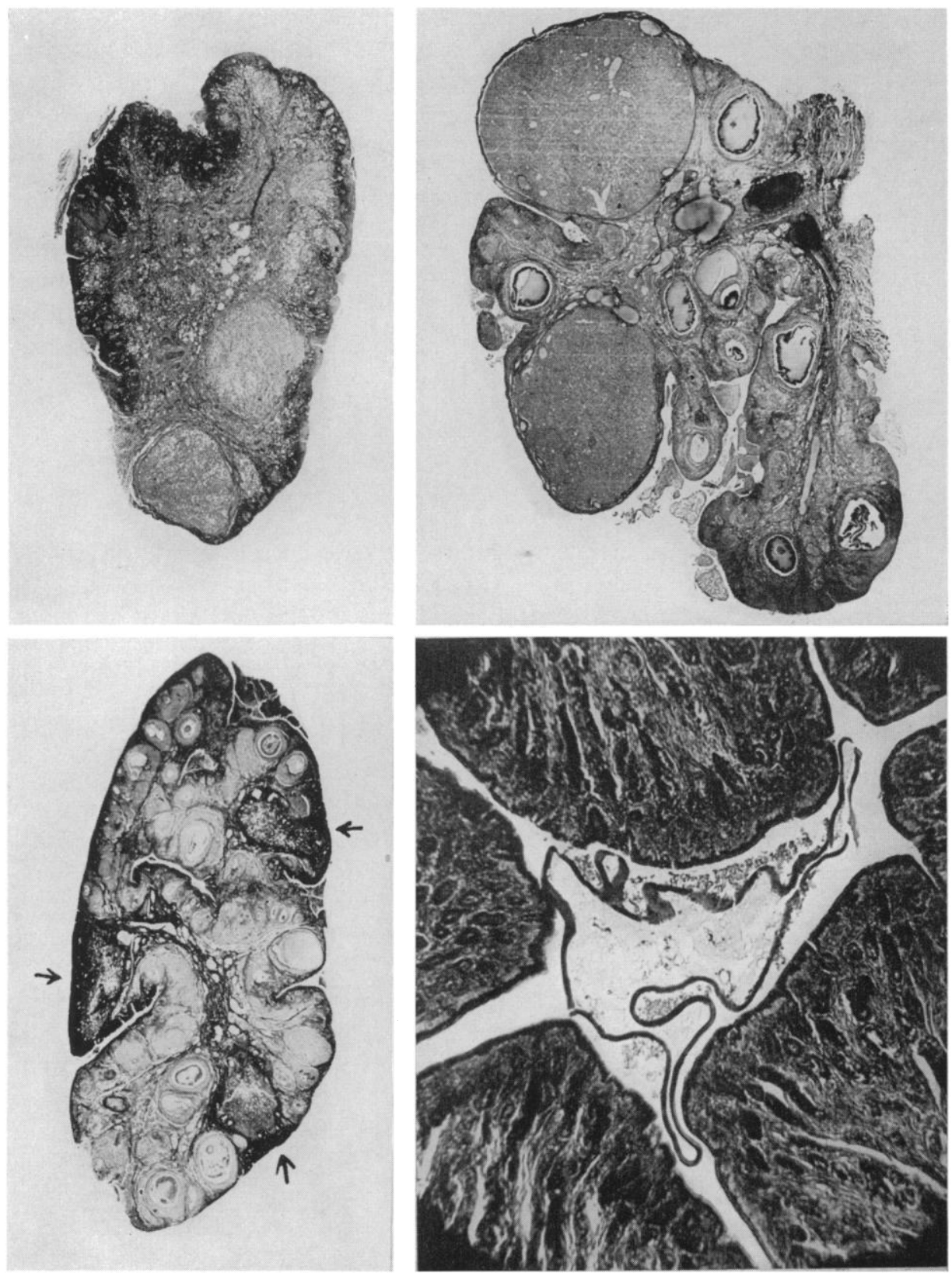

PLATE I

UPPER LEFT: Ovary of adult female with unimplanted blastocysts, showing two inactive corpora lutea. Animal killed in January. About $8.5 \times$. Upper Right: Ovary of adult female with $68 \mathrm{~mm}$. CR embryos showing two large active corpora lutea. Animal killed February 2. About $8.5 \times$. LOwER LEFT: Ovary of adult female during lactation showing three degenerating corpora lutea (shown with arrows) and absence of large follicles. Animal killed April 9. About 8.5 $\times$. Lower Right: Blastocyst of wolverine in situ in the lumen of the uterus. The conspicuous zona pelucida surrounds the embryo. Several nuclei can be seen within the embryo. From animal killed October 18. About $77 \times$. 
TABLE 2.-Summary of information on position, size, and numbers of cells in wolverine blastocysts

\begin{tabular}{c|c|l|c}
\hline Date killed & Position of blastocyst & Dimensions in microns & No. of cells counted \\
\hline \multirow{2}{*}{ Oct. 18, '53 } & Up. 1/3 L. U. & $783 \times 513 \times 840$ & 673 \\
& Low. 1/3 L. U. & $810 \times 378 \times 611$ & 387 \\
Nov. 1, '51 51 . & Up. 1/3 R. U. & $1053 \times 880 \times 108$ & 1024 \\
& Up. 1/3 R. U. & $1485 \times 1120 \times 189$ & 987 \\
& Up. 1/3 L. U. & $1283 \times 870 \times 189$ & 1077 \\
Jan. '50 & Mid. 1/3 L. U. & $999 \times 590 \times 378$ & 873 \\
& Mid. 1/3 L. U. & $615 \times 459 \times 202$ & 47 \\
& Low. 1/3 L. U. & $1290 \times 1013 \times 1188$ & 630 \\
& R. U. & $1188 \times 940 \times 189$ & 980 \\
& R. U. & $1012 \times 620 \times 270$ & 1513 \\
\hline
\end{tabular}

The interstitial tissue has undergone considerable regression. There are numerous medium-sized follicles.

The ovaries of the two lactating females show degenerating corpora; in one case they are scarcely recognizable (Pl. I). These ovaries consist mainly of interstitial cell masses or corpora atretica. The interstitial cells are more numerous than in the active pregnancy stages. The lack of large follicles and the general inactivity of these ovaries makes it clear that the female wolverine does not have an estrous period shortly after parturition as has been reported for the fisher (Hall, 1942).

Placental scars could not be seen externally in the two tracts of lactating animals but when the uteri were bleached in hydrogen peroxide and dehydrated and cleared in methyl salicylate the ring-shaped scars could be seen distinctly.

The uterus of one of the animals with unimplanted embryos appeared somewhat larger and the macroscopic blood vessels were conspicuous. Histologically the blood vessels showed thick hyalinized walls and it is thought that this animal may have been parous.

Description of the blastocysts.-Ten blastocysts were located in the three adult animals taken during the period of inactive pregnancy (Pl. I). The most conspicuous thing about these embryos is the heavy zona pellucida, about $7.8 \mathrm{mi}$ crons in thickness, which can be seen even in the freshly mounted unstained ribbons. The embryos are lying completely free in the lumen of the uterus, and all are partly collapsed and some completely so. They are well enough preserved so that nuclear counts can be made but not well enough to distinguish between inner cell mass and trophoblast cells. They are similar to the blastocysts of field-preserved marten (Wright, 1942) but are larger and have more cells. Information on size, distribution, and cell counts is summarized in Table 2.

There is a great variation in the size of these blastocysts and in the number of cells of which they are composed. It is difficult to estimate their original size before collapse but they were probably about $2 \mathrm{~mm}$. in diameter. The blastocysts may be at any position in the lumen of the uterus and the spacing of the embryos prior to implantation has not occurred in any of the animals. In the two lactating animals migration of some of the embryos from the right to the left uterine horn 
TABLE 3.-Findings in male reproductive tracts of Gulo

\begin{tabular}{|c|c|c|c|c|}
\hline Date killed & $\begin{array}{l}\text { Weight of } \\
\text { baculum }\end{array}$ & $\underset{\text { age }}{\text { Estimated }}$ & $\begin{array}{l}\text { Paired combined weight of } \\
\text { testes and epididymides }\end{array}$ & Presence of sperm \\
\hline July 22, '52 & 462 & Juv. & 1775 & None \\
\hline Oct. $28, ' 51$ & 1160 & $\mathrm{Im}$. & 1743 & None \\
\hline Nov. 1, '51 & 2755 & Ad. & 4160 & None \\
\hline Nov. 1, '51 & 735 & $\operatorname{Im}$. & 1365 & None \\
\hline Nov. 1, '51 & Incomplete & Ad. & 2098 & None \\
\hline Dec. $10, ' 51$ & 1780 & Ad. & 1980 & None \\
\hline Dec. 11, '51 & 653 & Im. & - & - \\
\hline Dec. $27, ' 51$ & 1015 & Im. & 1698 & None \\
\hline Jan. 6, '52 & 1890 & Ad. & 3225 & None \\
\hline Jan. 19, '52 & 2475 & Ad. & 3325 & None \\
\hline Jan. 25, '52 & 1359 & $\mathrm{Im}$. & 1075 & None \\
\hline Feb. 4, '53 & 2022 & Ad. & 8640 & $\begin{array}{l}\text { Spermatogenesis beginning, } \\
\text { no sperm in epididymis }\end{array}$ \\
\hline Feb. 21, '52 & 1175 & Im. & 3400 & None \\
\hline Feb. 28, '52 & 920 & Im. & 1645 & None \\
\hline Feb. $28, ' 52$ & 2483 & Ad. & 4480 & None \\
\hline Mar. 25, '52 & 1373 & $\operatorname{Im}$. & 1355 & None \\
\hline Mar. 26, '53 & 1215 & $\mathrm{Im}$. & 3300 & None \\
\hline Mar. 31 , '53 & 1458 & Im. & 5020 & $\begin{array}{l}\text { Few sperm in testis, none in } \\
\text { epididymis }\end{array}$ \\
\hline Mar. 31, '53 & 1009 & Im. & - & - \\
\hline Apr. 4, '52 & 1429 & $\mathrm{Im}$ & 6110 & $\begin{array}{l}\text { Few sperm in testis, none in } \\
\text { epididymis }\end{array}$ \\
\hline Apr. 4 , '52 & 2940 & Ad. & 14070 & $\begin{array}{l}\text { Active spermatogenesis, } \\
\text { some sperm in tail of } \\
\text { epididymis }\end{array}$ \\
\hline Apr. 16, '53 & 1242 & $\mathrm{Im}$. & 2530 & None \\
\hline
\end{tabular}

had occurred since all of the corpora lutea were in the right ovaries and placental scars were found in the left horns of both animals.

In two of the animals in inactive pregnancy a blastocyst was located for each corpus luteum. In the other, only two blastocysts were found although there were four corpora in the ovaries. In this case one small structure, 170 microns in greatest length, with distinct zona pellucida was found. There are small bodies within the zona which do not stain and it is thought that this is an embryo that died during cleavage. The other potential embryo was not located but it may have been lost if it were lying very close to one of the cuts made in preparing the uterus for imbedding.

The general picture of reproduction in the female wolverine can be seen from the data derived from the seven adult animals. Breeding takes place sometime between April and October, likely in midsummer. Development of the embryos is arrested when the blastocyst stage is reached and the embryos remain in this condition until January when implantation occurs. The young seem to be born in late March or early April. The number of young ranges from two to four. There may be loss of potential young prior to implantation or after implantation. Females apparently do not become pregnant during their first summer. 
Males.-The baculum of adult males is between 80 and $90 \mathrm{~mm}$. in length (Pl. II). It is nearly straight but the distal end may be bent dorsally 15 or 20 degrees at about one-third of the way from the tip. The bone is round or oval in cross section and the base is enlarged somewhat. If viewed from the anterior end the tip is seen to be expanded into a three pronged inverted Y. In animals judged to be immature the bone is less massive and the basal end less well developed. Seven bacula from animals thought to be adults weighed from $1780 \mathrm{mg}$. to 2940 mg. and averaged $2338 \mathrm{mg}$., while 13 bacula from immature animals weighed from 653 to $1458 \mathrm{mg}$. and averaged $1134 \mathrm{mg}$. One baculum of the adult type had the tip cut off and was therefore not weighed. The baculum from a half-grown young obtained on July 22 weighed only $462 \mathrm{mg}$.

It is well known from the work of Deanesly (1935), Elder (1951) and Wright (1947) that the baculum of mustelids develops to full size only after the animal has reached sexual maturity, and Wright (1950) has shown that in Mustela frenata the presence of male hormone is necessary for maturation of the baculum. Accordingly those wolverines with small bacula are judged to be sexually immature.

The testes and epididymides of six adult and ten immature males taken during the fall, winter and early spring months were undeveloped and aspermatic (Table 3). Unmistakable evidence of sexual activity was seen in only four animals. An adult taken on February 4 with testes weighing $8640 \mathrm{mg}$. showed sperm production in the testis, but no sperm had reached the epididymis. An adult taken on April 4 with testes weighing $14,070 \mathrm{mg}$. was in active spermatogensis and sperm were present in the tail of the epididymis. Two males considered immature on the basis of their bacula, taken on March 31 and April 4 were apparently just becoming active. A few sperm were in the testes but none in the epididymides. Probably full sexual activity would be found in adult males obtained in late spring or early summer. It is obvious that, since all males killed during November, December and January were without sperm, a winter breeding season can not occur in this species. At the time of implantation the males were sexually quiescent.

Skulls.-The juvenile male taken on July 22, thus about four months old, had almost the entire lacteal dentition in place. All of the sutures were still open but the skull was already as large in several measurements as that of an adult female. The remaining skulls all came from animals taken in October or later and were thus from animals at least six months old. All of these skulls show the

TABLE 4.-Means of cranial measurements of wolverines

\begin{tabular}{l|c|c|c|c|c|c}
\hline $\begin{array}{c}\text { Number and } \\
\text { classification }\end{array}$ & $\begin{array}{c}\text { Greatest } \\
\text { length of } \\
\text { skull }\end{array}$ & $\begin{array}{c}\text { Condylobasal } \\
\text { length }\end{array}$ & $\begin{array}{c}\text { Zygomatic } \\
\text { breadth }\end{array}$ & $\begin{array}{c}\text { Post-orbital } \\
\text { processes }\end{array}$ & $\begin{array}{c}\text { Post-orbital } \\
\text { constriction }\end{array}$ & $\begin{array}{c}\text { Length of } \\
\text { sagittal } \\
\text { crest }\end{array}$ \\
\hline 7 ad. males.......... & 161.6 & 146.8 & 106.1 & 48.7 & 34.1 & 76.3 \\
13 im. males........ & 157.7 & 146.1 & 104.0 & 47.9 & 35.2 & 68.9 \\
7 ad. females ....... & 147.8 & 135.8 & 97.8 & 46.5 & 33.4 & 62.4 \\
3 im. females ........ & 144.1 & 134.9 & 94.4 & 43.4 & 33.4 & 55.0 \\
\hline
\end{tabular}



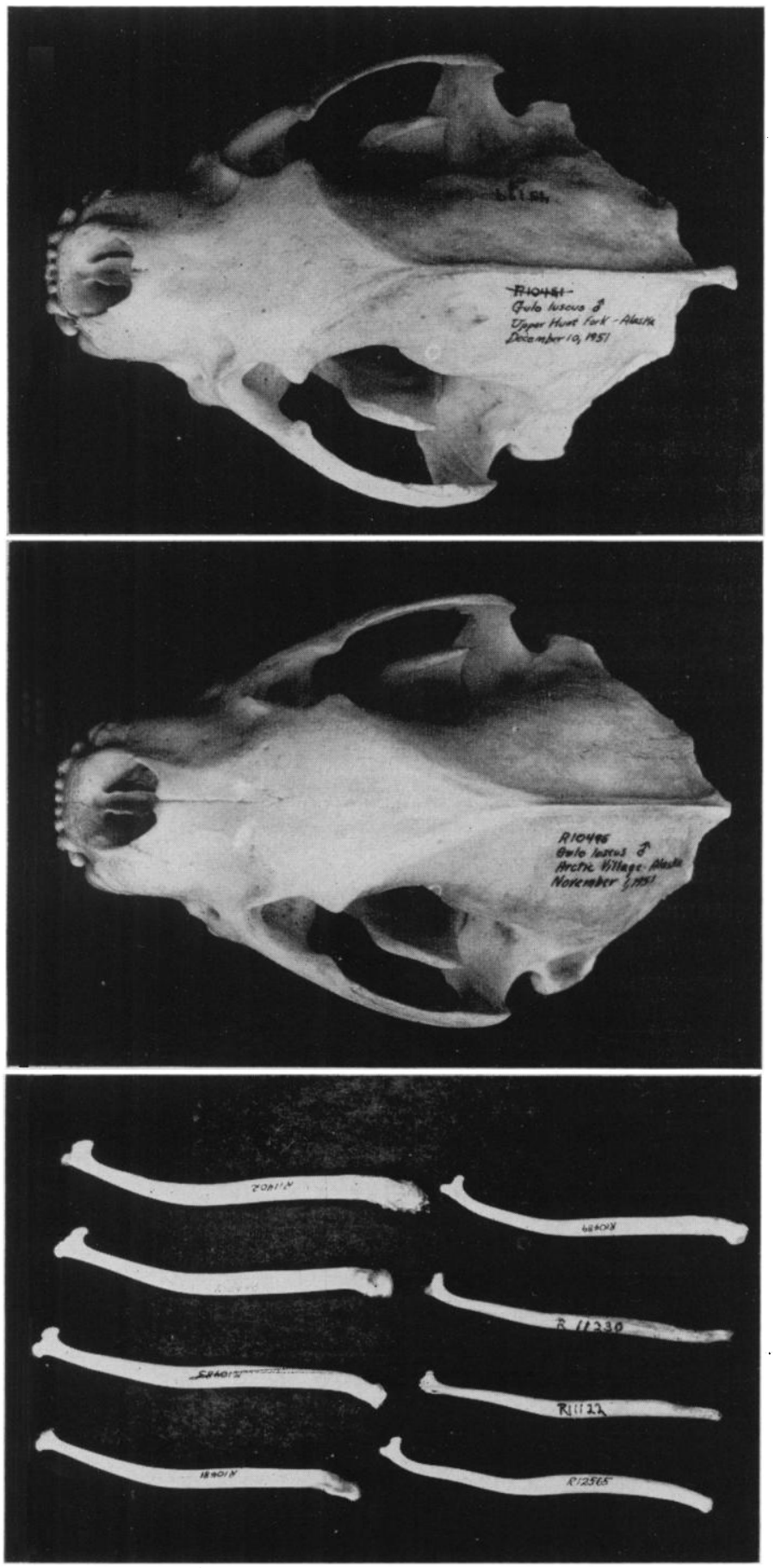

PLATE II

UPPER: Skull of adult male wolverine showing that all sutures have disappeared. The caudal extension of the sagittal crest is clearly shown. About $1 / 2$ natural size. Midde: Skull of immature male wolverine showing the internasal, naso-maxillary, the naso-frontal and the malar-temporal sutures still open. The sagittal crest is less well developed than in the adult male. About 1/2 natural size. Lower: Bacula of adult males on the left and immature males on the right. About $1 / 2$ natural size. 
great majority of the sutures to have disappeared, the permanent dentition is present and in males the sagittal crest is well developed (Plate II). Other writers such as Coues (1877) and Grinnell, Dixon and Linsdale (1937) have remarked about the rapid maturity of the skull in this species.

Means of measurements of the skulls were summarized according to sex and age in Table 4, the immatures separated from the adults on the basis of the reproductive tracts. No one of the cranial measurements taken seems to be critical alone in distinguishing adults from immatures. It would appear that the longer sagittal crest in adult males might distinguish them from the immatures but the $t$ test shows this difference is not significant. In adult males the sagittal crest seems to extend posteriorly further than in the immatures. A measurement of this character can be obtained indirectly by subtracting the condylobasal length from the greatest length of the skull. In seven adult males this averaged $14.9 \mathrm{~mm}$. and in twelve immature males it is $11.6 \mathrm{~mm}$. Although there is some overlap in individual cases, when analyzed by the $t$ test the difference was found to be significant at the 5 per cent level suggesting that this is a real difference. The same situation is probably true in the females but the number of skulls is not large enough to permit the use of tests of significance.

All of the animals judged to be adults have all of the usual sutures closed. All the immatures taken in the fall and early winter have the malar-temporal, the internasal, and the naso-maxillary sutures still open. Some of the males with small bacula taken in March and April and thus judged to be about one year old have some or all of these sutures closed.

The degree of tooth wear does not seem to be of great significance in estimating age, especially since animals of both classes may show broken teeth partly caused by fighting the trap.

A ratio of eight adult males to 13 immature males was obtained and of seven adult females to only four immature females. In view of these different ratios of young to adults in the two sexes, one might ask if there were reason to suppose that the female wolverine matures a year earlier than does the male. A comparison of these ratios by the chi-square method indicates that there is no reason to suspect this since the calculated value of chi-square is not significant and ratios of eight to 13 and seven to four could be drawn from the same population with considerable frequency. Also the fact that only one type of skull appears in winter-killed immatures suggests rather strongly that there is only one age class of immature animals represented in this sample. It would logically follow that animals of both sexes mature during their second summer.

\section{SUMMARY}

The reproductive tracts of 22 male and 11 female wolverines taken mostly during the fall, winter, and early spring months in northern Alaska have been studied. Adult females taken in October, November, and January showed unimplanted blastocysts in their uteri and inactive corpora lutea in their ovaries. Ten blastocysts ranging in number from two to four per female were recovered. The blastocysts may have several hundred cells and they are about $2 \mathrm{~mm}$. in diam- 
eter. A late-January and an early-February specimen had implanted embryos of 22 and $68 \mathrm{~mm}$. crown-rump length respectively. Two early-April specimens were lactating but not pregnant. Four females were immature. The wolverine has a long period of gestation like many of the other mustelids. The breeding season is not precisely known but it probably occurs in mid-summer.

The baculum of the male is described. Immature males may be distinguished from adult males by their smaller bacula. The testes of males of both ages were largely inactive during the winter months. Full sexual activity was seen in only one male taken in early April.

The skull of the wolverine matures rapidly, but the young during the first year tend to show open sutures in the facial and zygomatic regions. The sagittal crests of first year animals do not extend as far posteriorly as do those of adults.

\section{LITERATURE CITED}

Coues, E. 1877. Fur-bearing animals: a monograph of North American Mustelidae. Dept. Interior Misc. Publ. no. 8: 38 .

Deanesly, R. 1935. The reproductive processes in certain mammals. IX. Growth and reproduction in the stoat (Mustela erminea). Phil. Trans. Roy. Soc. London B., 225: 459-492.

Elder, W. H. 1951. The baculum as an age criterion in mink. Jour. Mamm., 32: 43-50.

Grinnell, J., J. Dixon, and J. M. Linsdale. 1937. Fur-bearing mammals of California, their natural history, taxonomic status and relations to man. Univ. California Press, Berkeley. vol. 1: 253.

HALL, E. R. 1942. Gestation period in the fisher with recommendations for the animal's protection in California. Calif. Fish and Game, 28: 143-147.

Hamlets, G. W. D. 1935. Delayed implantation and discontinuous development in mammals. Quart. Rev. Biol., 10: 432-447.

Moнr, E. 1938, 1939. Vom Järv (Gulo gulo L.). Zool. Gart. Lpz., 10 (1 and 2) : 14-21.

Rausch, R. 1953. On the status of some arctic mammals. Arctic 6:91-148.

Seton, E. T. 1927. Lives of game animals. Doubleday, Doran and Co. Garden City, N. Y. vol. 2: 416-420.

Wright, P. L. 1942. Delayed implantation in the long-tailed weasel (Mustela frenata), the short-tailed weasel (Mustela cicognani), and the marten (Martes americana). Anat. Rec., $83:$ :341-353.

1947. The sexual cycle of the male long-tailed weasel (Mustela frenata). Jour. Mamm., 28: 343-352.

1950. Development of the baculum of the long-tailed weasel. Proc. Soc. Exp. Biol. and Med., 75: 820-822.

Department of Zoology, Montana State University, Missoula and Arctic Health Research Center, Public Health Service, U.S. Department of Health, Education, and Welfare, Anchorage, Alaska. Received October 25, 1954. 